\title{
Correction to: SHP2 mutations induce precocious gliogenesis of Noonan syndrome-derived iPSCs during neural development in vitro
}

Younghee Ju', Jun Sung Park², Daejeong Kim³ , Bumsoo Kim', Jeong Ho Lee ${ }^{2}$, Yoonkey Nam³ ${ }^{3}$ Han-Wook Yoo ${ }^{4}$, Beom Hee Lee ${ }^{4}$ and Yong-Mahn Han ${ }^{1 *}$

Correction to: Stem Cell Res Ther (2020) 11: 209

https://doi.org/10.1186/s13287-020-01709-4

The original article [1] contained an error in Fig. 2 whereby the 2nd panel in the top row of Fig. 2A was mistakenly blanked during the production process by the team handling the manuscript. Fig. 2A in the original article has since been corrected.

\section{Author details}

'Department of Biological Sciences, KAIST, Daejeon 34141, Republic of Korea. ${ }^{2}$ Graduate School of Medical Science and Engineering, KAIST, Daejeon 34141, Republic of Korea. ${ }^{3}$ Department of Bio and Brain Engineering, KAIST, Daejeon 34141, Republic of Korea. ${ }^{4}$ Department of Pediatrics, Asan Medical Center Children's Hospital, University of Ulsan College of Medicine, Seoul 05505, Republic of Korea.

Published online: 16 July 2020

\section{Reference}

1. Ju Y, et al. SHP2 mutations induce precocious gliogenesis of Noonan

syndrome-derived iPSCs during neural development in vitro. Stem Cell Res Ther. 2020;11:209 https://doi.org/10.1186/s13287-020-01709-4.

\footnotetext{
The original article can be found online at https://doi.org/10.1186/s13287020-01709-4.

* Correspondence: ymhan@kaist.ac.kr

'Department of Biological Sciences, KAIST, Daejeon 34141, Republic of Korea

Full list of author information is available at the end of the article
}

(c) The Author(s). 2020 Open Access This article is licensed under a Creative Commons Attribution 4.0 International License, which permits use, sharing, adaptation, distribution and reproduction in any medium or format, as long as you give appropriate credit to the original author(s) and the source, provide a link to the Creative Commons licence, and indicate if changes were made. The images or other third party material in this article are included in the article's Creative Commons licence, unless indicated otherwise in a credit line to the material. If material is not included in the article's Creative Commons licence and your intended use is not permitted by statutory regulation or exceeds the permitted use, you will need to obtain permission directly from the copyright holder. To view a copy of this licence, visit http://creativecommons.org/licenses/by/4.0/ The Creative Commons Public Domain Dedication waiver (http://creativecommons.org/publicdomain/zero/1.0/) applies to the data made available in this article, unless otherwise stated in a credit line to the data. 